ISSN : $2620-4665$ (print)

ISSN : 2620 - 4673 (online)

Website : http://jurnal.untan.ac.id/index.php/JPLP2KM

\title{
KAJIAN KEMAMPUAN LITERASI KUANTITATIF SISWA SMA 8 KOTA BENGKULU
}

\author{
Siska Yosmar ${ }^{*}$, Nur Afandi², Baki Swita ${ }^{3}$ \\ 1,2,3 Jurusan Matematika FMIPA Universitas Bengkulu \\ *email: siskayosmar@unib.ac.id
}

\begin{abstract}
Quantitative literacy is the ability and confidence in using basic mathematical concepts and calculating operations needed for problem solving, decision making of economic problems and their applications in everyday life. Mastery of basic mathematics is an absolute requirement for achieving good quantitative literacy skills. The aim of this activity was to improve mathematical literacy skills of the students at SMA 8 Bengkulu City. The activities were begun by giving pretests to students, preparing of modules, presenting the materials of the modules in classroom, practicing through LKS and post-tests. Several techniques, methods and approaches in number counting operations have been presented in this activity. This activity has provided an increase in quantitative literacy skills in class XI IIS-1 SMA 8 Kota Bengkulu. Even so, the improvement of students' abilities can be said to be less optimal because there are still some questions that cannot be answered by almost all students. Therefore, cooperation and involvement of all parties is needed to improve students' quantitative literacy skills and follow-up activities in an effort to strengthen quantitative literacy skills.
\end{abstract}

Keywords: quantitative literacy, basic mathematics, counting operations

\section{PENDAHULUAN}

Dalam kehidupan sehari-hari hampir semua aspek berhubungan dengan angka dan data. Ketika beraktifitas dimana saja, hampir pasti akan berhadapan dengan angka dan data. Bailey (1996) dan Steen (2001) mengemukakan bahwa angka dan data akan memenuhi dunia disekitar kita, sehingga untuk survive dalam menjalani kehidupan sangat dibutuhkan kemampuan untuk memahami dan menggunakan angka dan data. Secara umum kemampuan ini terkait dengan literasi kuantitatif (quantitative literacy).

Secara sederhana literasi kuantitatif adalah kemampuan untuk menggunakan angkaangka dan analisis data dalam kehidupan sehari-hari. Menurut Hallet dalam Fauzan (2016) literasi kuantitatif juga diartikan sebagai kebiasaaan berpikir (habit of mind), kompetensi, dan kelancaran dalam bekerja dengan data numerik. Oleh sebab itu literasi kuantitatif sangatlah penting dimiliki oleh seseorang karena data dan angka tidak dapat dipisahkan dari kehidupan. 
Literasi kuntitatif erat kaitannya dengan matematika. Steen (2001) menyatakan bahwa literasi kuantitatif tidak hanya melibatkan kemampuan tetapi juga kepercayaan diri dalam menggunakan konsep-konsep dasar matematika dan operasi-operasi hitung yang diperlukan untuk pemecahan masalah, pengambilan keputusan, dan untuk menyelesaikan masalah ekonomi serta aplikasinya dalam kehidupan sehari-hari. Hal ini menunjukkan bahwa penguasaan matematika dasar menjadi syarat mutlak untuk mencapai kemampuan literasi kuantitatif yang baik. Meskipun literasi matematika sangat terkait dengan matematika, namun orang yang telah belajar matematika belum tentu akan memiliki literasi kuantitatif yang baik.

Faktanya meskipun telah mempelajari matematika sejak sekolah dasar, namun masih banyak orang dengan kemampuan literasi kuantitatif yang minim. Misalnya saja, berdasarkan pengalaman penulis masih banyak mahasiswa program S1 yang melakukan kesalahan dalam operasi bilangan pecahan, masih banyak mahasiswa yang gagal mendeskripsikan grafik dan data.

Merujuk pada pernyataan Steen (2001) di atas, orang dengan kemampaun literasi kuantitatif yang rendah akan sangat mungkin gagal dalam membuat keputusan-keputusan penting, terutama yang terkait dengan data dan angka. Keputusan yang diambil bisa saja menjadi tidak tepat karena tidak didukung oleh kemampuan dalam memahami angka dan data dengan baik.

Telah menjadi rahasia umum bahwa matematika merupakan pelajaran yang sangat ditakuti dan tidak disukai oleh kebanyakan siswa. Beberapa diantaranya bahkan tidak dapat menyelesaikan persoalan-persoalan matematika yang sederhana. Beberapa lainnya tidak mengerti apa yang mereka kerjakan. Hal ini sejalan dengan pendapat Armanto (2002) yang mengungkapkan bahwa banyak siswa yang mampu menjalankan serangkaian prosedur pembagian tetapi mereka tidak memahami apa yang dilakukan.

Salah satu dampak ketidaksukaan seseorang terhadap matematika adalah kemampuan literasi yang dimilikinya cukup rendah. Hal ini tentu saja akan menjadi hambatan bagi siswa di masa sekarang, dalam hal menerima materi lanjutan, dan juga di masa mendatang, baik bagi mereka yang ingin melanjutkan ke pendidikan tinggi ataupun bagi mereka yang ingin memasuki dunia kerja. Hal ini menunjukkan bahwa dampak lemahnya kemampuan matematika dasar dan juga kemampuan literasi kuantitatif tidak bisa dianggap sebagai hal yang sepele. Oleh karena itu, 
ISSN : $2620-4665$ (print)

ISSN : 2620 - 4673 (online)

Website : http://jurnal.untan.ac.id/index.php/JPLP2KM

melalui kegiatan pengabdian ini merupakan salah satu upaya untuk meningkatkan literasi kuatitatif siswa.

\section{TINJAUAN PUSTAKA}

Bailey (1996) dan Steen (2001) mengemukakan bahwa angka dan data akan memenuhi dunia di sekitar kita, sehingga untuk survive dalam menjalani kehidupan sangat dibutuhkan kemampuan untuk memahami dan menggunakan angka dan data tersebut. Secara umum kemampuan ini terkait dengan literasi kuantitatif (quantitative literacy).

Secara sederhana literasi kuantitatif adalah kemampuan dalam menggunakan angka dan analisis data dalam kehidupan sehari-hari. Menurut Hallet dalam Fauzan (2016) literasi kuantitatif juga diartikan sebagai kebiasaaan berpikir (habit of mind), kompetensi, dan kelancaran dalam bekerja dengan data numerik. Sementara itu menurut Steen (2001) literasi kuantitatif tidak hanya melibatkan kemampuan tetapi juga kepercayaan diri dalam menggunakan konsep-konsep dasar matematika dan operasi-operasi hitung yang diperlukan untuk pemecahan masalah, pengambilan keputusan, dan untuk menyelesaikan masalah ekonomi serta aplikasinya dalam kehidupan sehari-hari.

Maount St. Mary's College telah menyusun indikator literasi kuantitatif secara hierarkis sebagai berikut.

1. Melakukan operasi-operasi perhitungan dasar/aritmatika secara kompeten, kompeten dalampenjumlahan, pengurangan, perkalian, pembagian, pecahan dan persenase tanpa bantuan kalkulator atau alat hitung lainnya.

2. Terampil dalam mengestimasi atau mengaprokmasi suatu hasil, yaitu mampu memperkirakan rentang jawaban yang mungkin serta mengidentifikasi bahwa suatu jawaban adalah tidak mungkin teoritis.

3. Kompeten melakukan operasi aljabar tau logika yang melibatkan abstraksi, yaitu mampu menyajikan suatu masalah dalam bentuk model matematika atau persamaan aljabar, menggunaan simbl-simbol dan menyelesaikan persamaan-persamaan aljabar.

4. Memiliki keterampilan pemecahan masalah, yaitu mampu mendefenisikan masalah, merencanakan pemecahan masalah, memprediksi kemungkinan solusi, menganalisa dan mengevaluasi solusi yang ditawarkan, mengenal asumsi yang tidak diperlukan, mempertimbangkan penjelasan alternatif dan memeriksa kecocokan solusi dengan data awal. 
5. Kompeten dalam mengaplikasikan keterampilan analitis, yaitu mampu menyusun argument, mampu menggunakan penalaran induktif dan dedukti, mengajukan buktibukti dan melakuan infensi, membaca dan memahami grafik-gafik sederhana, melakukan analisis data sederhana, melakukan operasi-operasi sederhana dalam bidang keuangan (contoh : memeriksa keseimbangan buku kas, menghitung bunga dan lain-lain) dan mentransfer keteramplan matematis dan analitis pada bidang lain atau pada situasi dunia nyata.

Literasi kuantitatif sangat berkaitan dengan kemampuan matematika. Meskipun demikian, orang yang telah belajar matematika belum tentu akan memiliki literasi kuantitatif yang baik. Armanto (2002) mengungkapkan bahwa banyak siswa yang mampu menjalankan serangkaian prosedur pembagian tetapi mereka tidak memahami apa yang dilakukan. Hal ini menunjukkan bahwa kemampuan matematika siswa belum dapat mengantarkannya untuk memiliki kemampuan literasi yang baik.

Johar (2012) menyampaikan bahwa adanya kesenjangan antara tujuan kurikulum dengan hasil yang diperoleh Indonesia pada penilaian (literasi kuantitatif) internasional. Pada dasarnya pemerintah Indonesia telah berusaha menyusun dan mengembangkan kurikulum yang membekali peserta didik agar mampu berpikir logis, analitis, sistematis, kritis, dan kreatif. Namun fakta yang terjadi tidak seperti yang diharapkan. Banyak hal yang perlu dikaji untuk mengetahui penyebabnya, seperti kualitas guru, sumber belajar, sistem evaluasi, dukungan masyarakat dan juga pemerintah sendiri.

\section{METODE}

Kegiatan pengabdian ini dilaksanakan pada bulan Juli hingga Agustus 2018 di SMA 8 Kota Bengkulu. Peserta kegiatan adalah siswa kelas XI IS-1. Adapun alasan dipilihnya siswa dengan minat IPS karena pada umumnya kemampuan matematika dasar siswa dengan minat IPS lebih rendah dibandingkan dengan siswa dengan minat IPA.

Kegiatan dilaksanakan dalam empat kali pertemuan, juga diberikan pre-test dan post-test untuk melihat apakah ada peningkatan kemampuan literasi kuantitatif siswa. Kegiatan pengabdian ini telah dilaksanakan dalam beberapa tahap. Berikut ini tahapan kegiatan yang telah dilaksanakan: 
ISSN : $2620-4665$ (print)

ISSN : 2620 - 4673 (online)

Website : http://jurnal.untan.ac.id/index.php/JPLP2KM

\section{1) Tahap Persiapan}

Pada tahap persiapan ini dilakukan pengumpulan informasi, pelacakan, dan survei kebutuhan dari siswa SMA 8 Kota Bengkulu, yang meliputi permasalahan yang dihadapi siswa terkait kemampuan literasi kuantitatif. Pelaksanaan tahap ini dilakukan melalui diskusi dan wawancara langsung dengan guru mata pelajaran Matematika tentang kemampuan matematika dasar siswa kelas IPS.

\section{2) Tahap Pelaksanaan}

Tahap pelaksanaan ini, dimulai dengan melaksanakan pre-test pada siswa kelas XI IS-1. Selanjutnya dilakukan penyusunan materi yang berkaitan dengan kemampuan literasi matematika. Penyusunan materi juga dilakukan berdasarkan hasil pre-test pada tahap persiapan. Materi-materi tersebut disusun dengan struktur: konsep, contoh soal, latihan, dan pembuatan kunci jawaban. Untuk lebih menjelaskan konsep, maka contoh soal dihubungkan dengan masalah yang kerap ditemui dalam kehidupan sehari-hari. Kemudian disiapkan beberapa soal latihan untuk dikerjakan sebagai latihan. Setelah materi selesai disusun, pelaksanaan dilaksanakan dalam dua pertemuan.

\section{3) Tahap Evaluasi}

Pada tahap ini dilakukan post-test terhadap siswa yang menjadi peserta workshop. Untuk melihat dampak kegiatan, hasil post-test siswa dibandingkan dengan hasil pre-test siswa. Kriteria yang digunakan adalah melihat kemampuan dan keterampilan siswa dalam mengerjakan soal yang diberikan dengan cepat, tepat dan benar. Indikator pencapaian tujuan pembinaan adalah hasil post-test. Kegiatan ini dianggap berhasil apabila pencapain hasil post-test meningkat dibandingkan hasil pre-test.

\section{HASIL DAN PEMBAHASAN}

Kegiatan Pengabdian Pada Masyarakat (PPM) yang dilaksanakan di SMA 8 Kota Bengkulu diikuti oleh siswa kelas XI IS-1 yang berjumlah 36 siswa. Kegiatan dimulai dengan mengadakan pre-test yang diikuti seluruh peserta. Soal pre-test dibuat dengan mempertimbangkan indikator literasi kuantitatif yang dikemukakan oleh Mount St. Mary's College. Soal ini dibagi menjadi lima kelompok sebagai berikut

Tabel. Klasifikasi Soal Pre-Test

\begin{tabular}{cl}
\hline Kelompok soal & \multicolumn{1}{c}{ Kemampuan yang dinilai } \\
\hline I & Operasi perhitungan dasar \\
II & Estimasi dan aproksimasi \\
II & Operasi aljabar yang melibatkan abstraksi \\
V & Keterampilan Pemecahan masalah \\
\hline
\end{tabular}


Soal pre-test terdiri dari 11 soal ang terdiri dari 4 soal kelompok I, 3 Soal kelompok II, 1 soal Kelompok III, 1 soal kelompok IV, dan 2 soal kelompok V. Kelompok soal I terdiri dari soal nomor 1, 2, 5 dan 8, kelompok soal II terdiri dari soal nomor 3, 4, dan 6, kelompok soal III terdiri dari soal no 9, kelompok soal IV terdiri dari kelompok soal II terdiri dari soal nomor 10, dan kelompok soal II terdiri dari soal nomor 7 dan 11.

Berdasarkan hasil pre-test diperoleh rata-rata nilai pre-test siswa adalah 30,83 dengan nilai tertinggi 60 dan nilai terendah 10. Dari 11 soal yang diberikan ternyata siswa hanya mampu menjawab beberapa soal saja. Rata-rata soal yang berhasil dijawab oleh siswa kurang dari 4 soal. Soal yang dapat dijawab dengan benar oleh kebanyakan siswa adalah soal nomor 1 dan 2 yaitu oleh 29 dan 32 siswa. Sementara itu untuk soal lainnya hanya mampu dijawab dengan benar oleh paling banyak 10 siswa, bahkan untuk soal nomor 3, 4, dan 5 tidak ada siswa yang dapat menjawab dengan benar.
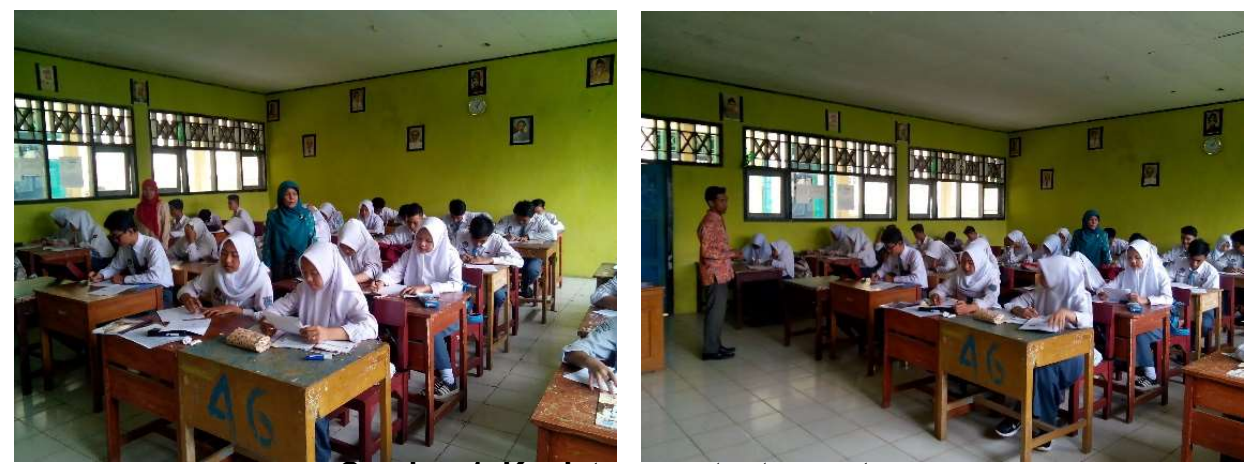

\section{Gambar 1. Kegiatan pre-test peserta}

Kolompok soal I merupakan kelompok soal dengan tingkat kesulitan paling rendah. Kelompok soal ini merupakan kelompok soal yang paling sukses dijawab oleh siswa. Namun demikian, hal ini juga belum dapat dikatakan baik karena dari 4 soal yang disediakan hanya dua soal saja yang berhasil dijawab oleh kebanyakan siswa. Soal nomor 5 sama sekali tidak dijawab sementara itu soal nomor 8 dijawab dengan benar hanya oleh 6 siswa saja. 
ISSN : $2620-4665$ (print)

ISSN : $2620-4673$ (online)

Website : http://jurnal.untan.ac.id/index.php/JPLP2KM

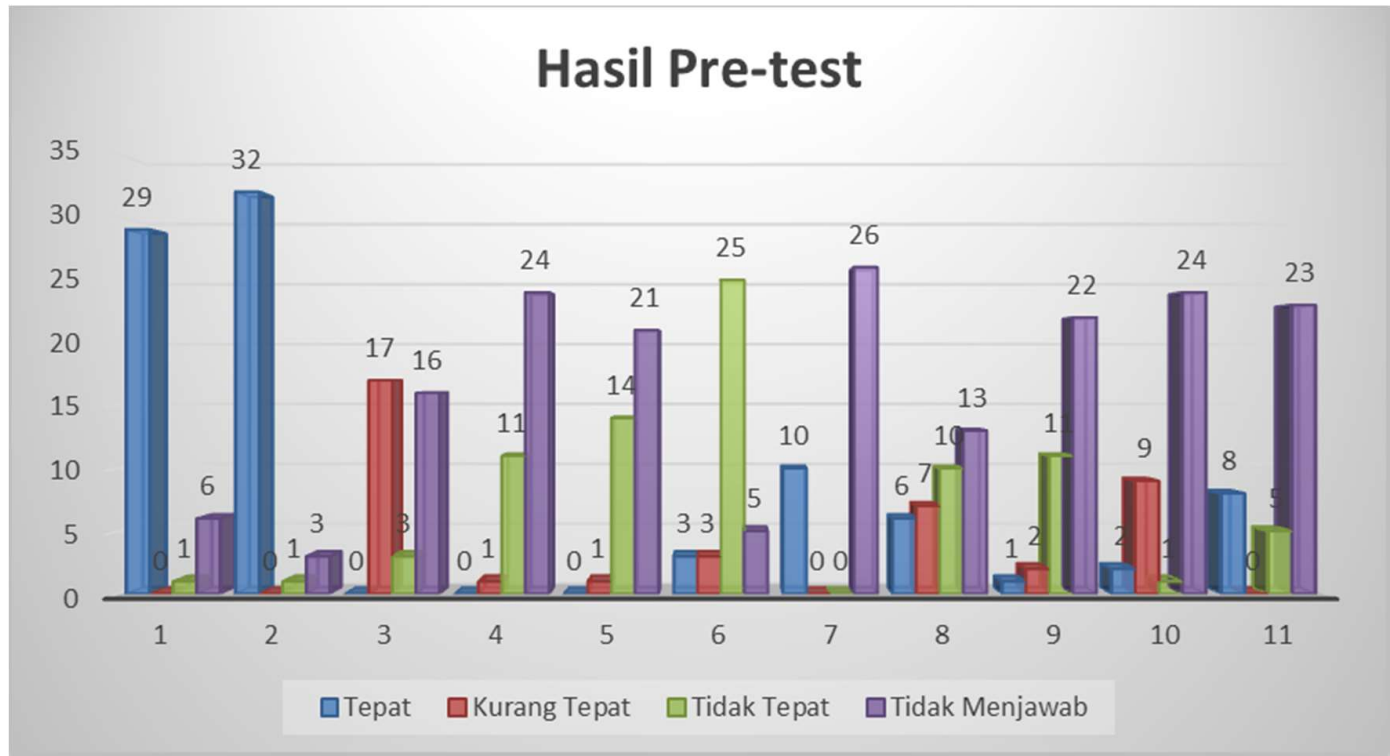

Gambar 2. Distribusi Jawaban Siswa Pada Soal Pre-test

Kelompok soal II, III, dan IV merupakan kelompok soal yang tidak dapat dijawab oleh hampir seluruh siswa. Bahkan partisipasi siswa dalam menjawab juga sangat rendah. Partisipasi siswa paling baik di kelompok soal ini ditunjukkan untuk soal nomor 6. Meskipun demikian, 25 siswa menjawab dengan tidak tepat dan 3 siswa menjawab dengan tidak sempurna.

Partisipasi siswa pada kelompok soal V cukup rendah. Namun demikian sebagian besar siswa yang menjawab soal pada kelompok ini, menjawabnya dengan benar. Pada soal nomor 7 semua siswa yag berpartisipasi menjawab dengan tepat, sementara itu dari 13 orang yang menjawab soal 11, 8 siswa diantaranya menjawab dengan tepat.

Hasil yang diperoleh pada hasil pre-test menunjukkan bahwa kemampuan literasi kuantitatif yang dimiliki siswa sangat rendah, bahkan untuk operasi perhitungan dasar. Oleh karena itu, sebagai upaya untuk membantu meningkatkan pemahaman siswa disusunlah modul dan LKS. Secara umum modul berisi tentang operasi dasar matematika berserta aplikasinya dalam kehidupan sehari-hari. Modul yang telah disusun disampaikan kepada siswa dalam dua pertemuan.

Pada pertemuan pertama diberikan materi tentang operasi hitung dan sifat-sifatnya. Berdasarkan obsevasi tim, siswa memberikan perhatiannya dan sangat antusias dalam menjalani pelatihan. Sebagai evaluasi pelatihan pada hari pertama, siswa diminta untuk menyelesaikan LKS yang telah dipersiapkan. Hasil yang baik diperlihatkan siswa pada hari pertama pelatihan. Rata-rata nilai LKS yang diperoleh siswa 82,72 dengan nilai tertinggi 96,2 dan 
nilai terrendah 59,3. Hal ini memberikan indikasi adanya peningkatan pemahaman siswa tentang operasi hitung dan sifat-sifatnya.

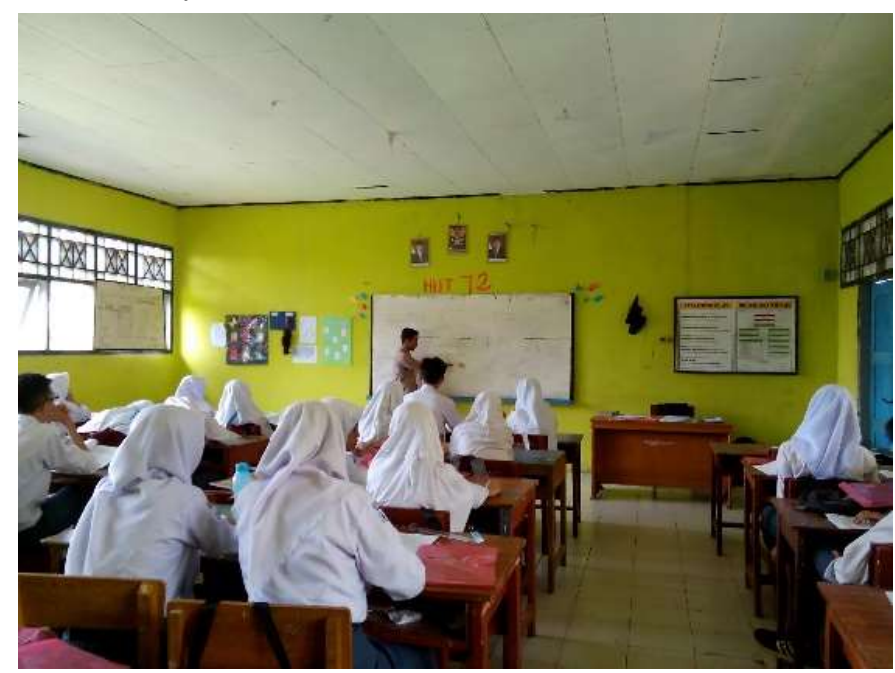

\section{Gambar 3. Kegiatan Pelatihan Literasi kuantitatif di SMA 8 Kota Bengkulu}

Pada pertemuan kedua diberikan materi yang berkaitan dengan aplikasi matematika dalam kehidupan sehari-hari antara lain nilai tukar mata uang asing, diskon, membaca data, dan peluang. Antusias siswa dalam mengikuti kegiatan semakin baik dibandingkan dengan pertemua pertama. Hal ini mungkin disebabkan materi kegiatan pelatihan lebih terkait dengan kehidupan sehari-hari. Disamping itu, penyajian materi dilakukan dengan menggunakan media yang dilengkapi dengan gambar yang bervariasi membuat suasana kelas tidak monoton.

Pertemuan selanjutnya, siswa diberikan post-test. Soal post-test berjumlah 12 soal yang terdiri dari 3 soal operasi perhitungan dasar (soal 1, 3, dan 6), 2 soal berkaitan dengan estimasi dan aproksimasi (soal 2b dan 7), 1 soal berkaitan dengan operasi aljabar yang melibatkan abstraksi (soal 8), 1 soal berkaitan dengan pemecahan masalah (soal 5), 4 soal berkaitan dengan keterampilan analitis (soal 2a, 4, 9, 10a, dan 10b). 
ISSN : $2620-4665$ (print)

ISSN : $2620-4673$ (online)

Website : http://jurnal.untan.ac.id/index.php/JPLP2KM

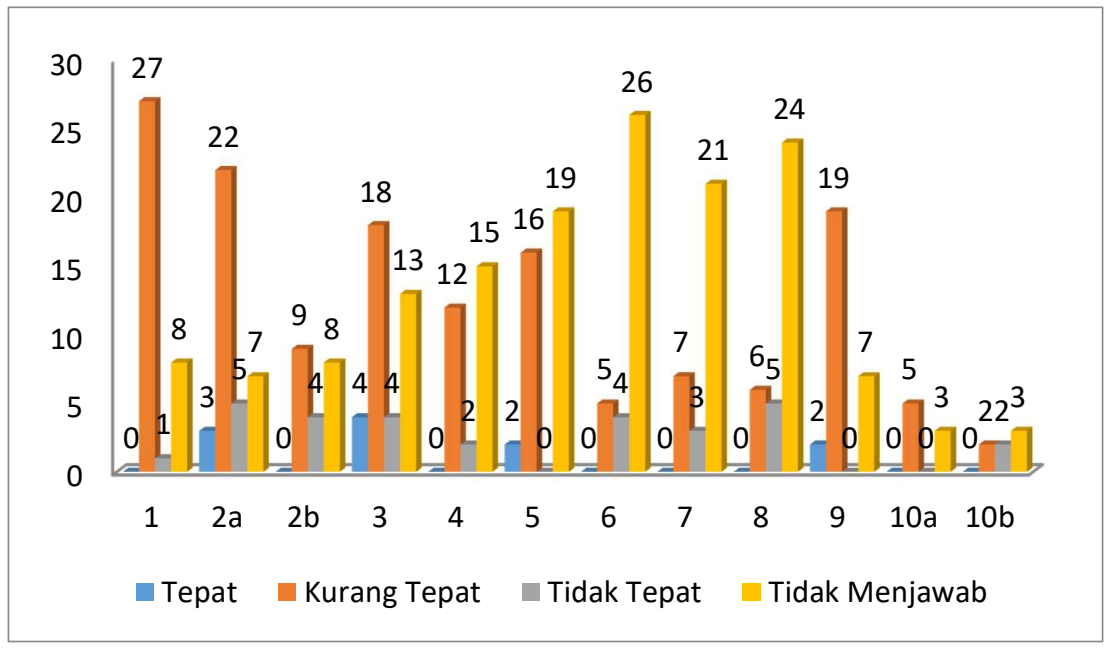

\section{Gambar 4. Distribusi Jawaban Siswa Pada Soal Post-test}

Distribusi jawaban pada soal post-test diperlihatkan dalam Gambar 4. Berdasarkan Gambar 4 tersebut, diketahui bahwa jumlah siswa yang menjawab dengan sempurna masih sangat sedikit. Sebagian besar siswa melakukan kesalahan dalam memberikan jawaban. Namun demikian kesalahan-kesalahan yang dilakukan hanya karena kesalahan-kesalahan kecil saja. Meskipun terjadi kesalahan-kesalahan dalam menjawab soal, namun hasil post-test menunjukkan adanya indikasi peningkatan kemampuan literasi siswa, yang dapat dilihat dari nilai rata-rata post-test siswa yaitu 42,2 dengan nilai tertinggi 73 dan nilai terrendah 14 .

Peningkatan kemampuan literasi kuantitatif siswa ini dapat dikatakan kurang optimal karena beberapa alas an. Misalnya a) terjadi kesalahan kecil dalam menjawab soal, b) masih ada beberapa soal yang sama sekali tidak bisa dijawab oleh hampir semua siswa, c) masih saja terjadi kesalahan dalam kelompok soal dengan tingkat kesulitan paling rendah.

Dari pembahasan di atas, dapat disimpulkan bahwa siswa belum memiliki tingkat kemampuan literasi kuantitatif yang diharapkan. Siswa umumnya masih sulit mengkaitkan antara operasi hitung beserta sifat-sifatnya dengan masalah-masalah sehari-hari yang bersifat kontekstual. Oleh karena itu, kegitan lanjutan sejenis dengan durasi yang lebih panjang sangat diperlukan.

\section{KESIMPULAN DAN SARAN}

\section{KESIMPULAN}

Diperlukan kerjasama dan keterlibatan semua pihak dalam upaya untuk meningkatkan kemampuan literasi kuantitatif siswa. Beberapa teknik, metode, dan cara pendekatan dalam 
operasi hitung bilangan telah disajikan dalam kegiatan ini. Kegiatan ini telah memberikan peningkatan kemampuan literasi kuantitatif siswa kelas XI IIS-1 SMA 8 Kota Bengkulu. Meskipun demikian peningkatan kemampuan siswa dapat dikatakan kurang optimal karena masih ada beberapa soal yang sama sekali tidak bisa dijawab oleh hampir semua siswa.

\section{SARAN}

Berdasarkan hasil evaluasi kegitan pengabdian yang telah dilakukan, diperlukan kegitan lanjutan dalam upaya penguatan kemampuan literasi kuantitatif siswa di SMA Negeri 8 Kota Bengkulu khususnya XI IIS-1.

\section{DAFTAR PUSTAKA}

Armanto, D. 2002. Teaching Multiplication and Division Realistically in Indonesian Primary Schools: a Prototype of Local Instructional Theory. Enschede, The Netherlands: Print Partners Ipskamp.

Bailey, J. 1996. After Thought: The Computer Challenge to Human Intelligence. New York: Basic Books

Fauzan, A. 2016. Literasi Kuantitatif: Sesuatu yang Terlupa dalam Pembelajaran Matematika. Disampaikan pada: Seminar Nasional Matematika dan Statistika 2016 di Jurusan Matematika FMIPA Universitas Negeri Padang. Padang

Johar, R. 2012. Jurnal Peluang. Domain Soal PISA untuk Literasi Matematika.

Steen, L.A. 2001. In Mathematics and Democracy: The Case for Quantitative Literacy.Princeton: National Council on Education and the Diciplines. 